\title{
Penerapan Model Student-Centered Learning di Lembaga Pendidikan Tenaga Kependidikan
}

\author{
Elizar $^{1}$ \\ Program Studi Pendidikan Bahasa dan Sastra Indonesia \\ STKIP Muhammadiyah Kotabumi
}

\begin{abstract}
Teaching model is important componen in education system. It helps education process in implementing the aim of education effectively an effeciently. So, every education must also be creative in selecting and using education model. Based on the past and todays experiences, quality of education in Indonesia showed that the quality of teaching and learning process done by teachers and students was still low. Learning paradigm still focused on a teacher only (teacher centered learning) that caused learning process unattractive and monotonous. There were some factors that made difficult to change teacher paradigm in teaching and learning activity, namely teacher's low commitment and skill in implementing active teaching-learning process. Therefore, teachers training institution (LPTK) should prepare the students to have skills in implementing active teaching and learning. One of some efforts that could be done to improve students' skill, as prospective teachers, in implementing an active learning was that by implementing SCL (Student Centered Learning). It covered modelling a lecturer as a model in implementing active learning in the class and it integrates active learning in small group discussion, role-play and simulation, case study, discovery learning, self-directed learning, cooperative learning, colloborative learning, contextual learning, project based learning, problem based learning and inquiry.

Kata Kunci: student teacher centered learning, teaching model.
\end{abstract}

\section{A. PENDAhuluan}

Guru merupakan agen pembelajaran dan merupakan kunci utama keberhasilan pendidikan, sehingga tidak mengherankan jika kemudian guru menjadi pihak yang dianggap paling bertanggung jawab terhadap baikburuknya kualitas pendidikan. Secara formal guru merupakan adalah sosok terdepan dalam upaya pendidikan dan pembelajaran. Sebagai agen pembelajaran, fungsi utama guru adalah meningkatkan mutu pendidikan nasional (UU No.14 tahun 2005).

Dalam rangka memenuhi tuntutan Undang-undang tersebut, maka pemerintah menetapkan empat kompetensi yang harus dimiliki oleh guru dalam menjalankan tugasnya, yaitu kompetensi pedagogik, kompetensi profesional, kompetensi kepribadian dan kompetensi sosial (PP No.19 tahun 
2005 Bab VI pasal 28 , UU No.14 tahun 2005 Bab IV pasal 10). Pada kompetensi profesional, seorang guru diharapkan mampu menguasai pelajaran sesuai bidang keilmuannya. Kemudian pada kompetensi pedagogik dituntut pula kemampuan guru untuk dapat pembelajaran dengan baik. Kompetensi kepribadian ditunjukkan dengan kepribadian yang mantap, berakhlak mulia, arif, berwibawa dan menjadi teladan bagi peserta didik. Sedangkan kompetensi sosial menuntut guru mampu berkomunikasi secara efektif dan efisien dengan peserta didik dalam rangka mewujudkan tujuan pembelajaran.

Beberapa hasil kajian dari dalam implementasi program pembelajaran di kelas, ternyata masih banyak yang belum memiliki keterampilan dalam mengelola pembelajaran dengan baik, mulai dari mendesain kegiatan pembelajaran, mengelola pembelajaran, hingga melakukan evaluasi dan perbaikan terhadap pembelajaran yang dilakukan. Gambaran ini menunjukkan rendahnya kompetensi yang dimiliki oleh guru (Depdiknas, 2004:4).

Ada banyak faktor yang menyebabkan kondisi di atas, salah satunya adalah rendahnya komitmen dalam menerapkan pembelajaran aktif. Banyak guru yang meskipun telah memperoleh pelatihan pembelajaran aktif ternyata tidak berubah ketika kembali ke kelas masing- masing, mereka tetap saja asyik dengan metode ceramah yang selama ini telah dilakukannya. Rendahnya komitmen ini ternyata dipengaruhi oleh paradigma guru dalam memandang pembelajaran itu sendiri, di mana pembelajaran dipandang sebagai transfer pengetahuan. Oleh karenanya guru harus sebanyak mungkin menyampaikan informasi dan pengetahuan kepada peserta didik, dan cara yang paling mudah dan efektif menurut mereka adalah dengan ceramah. Paradigma seperti inilah yang hingga saat ini menghambat jalannya penerapan pembelajaran aktif di sekolah.

Merubah paradigma guru tidak semudah seperti membalikkan telapak tangan. Guru yang sudah berpuluh tahun mengajar dengan metode ceramah satu arah dan berpusat pada guru (teacher centered learning, disingkat TCL ) tentu akan sulit berubah menjadi pembelajaran berpusat pada siswa (student centered learning, disingkat SCL ) dalam waktu sekejap. Alternatif yang dapat diupayakan yaitu melalui penataan penyelenggaraan lembaga pendidikan calon guru di Lembaga Pendidikan Tenaga Kependidikan (LPTK) itu sendiri. Lewat institusi ini dapat 
dilakukan dan dibenahi dan ditingkatkan kualitas pembelajaran di kelas selama masa persiapan mahasiswa sebagai calon guru. Dalam hal ini peningkatan kualitas pembelajaran dapat diupayakan melalui implementasi model mengajar yang sesuai dengan materi pembelajaran yang akan disampaikan dan tujuan yang hendak dicapai, sehingga diharapkan dapat meningkatkan kemampuan lulusan sebagai calon guru yang relevan dan dapat memenuhi kebutuhan masyarakat stakeholders sebagai penguna lulusan LPTK.

Di era globalisasi yang ditandai dengan kompetisi antar perguruan tinggi demikian ketat, dengan berbagai alasan mencakup kompetensi dan ketrampilan dosen dalam mengelola pembelajaran atau perkuliahan akan mempengaruhi minat belajar bagi para mahasiswa dan capaian pembelajarannya. Kualitas seorang dosen sangat dibutuhkan dalam memberikan kuliah terutama dalam mengelola pembelajaran. Dengan kata lain kompetensi diri seorang dosen sangat mempengaruhi minat belajar bagi para mahasiswanya dan capaian pembelajarannya. Dosen di LPTK haruslah memiliki kompetensi yang handal karena tugas yang diemban cukup berat. Peran dosen sangat penting untuk meningkatkan kualitas lulusan sebagai calon guru.
Ada 10 dasar kompetensi dosen yang harus di miliki oleh dosen sebagai syarat menjadi dosen yang profesional di LPTK yaitu :

1. Menguasai bahan (mata kuliah yang diajarkan)

2. Mengelola program belajar mengajar (dari persiapan perangkat mengajar sampai melaksanakan program belajar mengajar)

3. Mengelola kelas (mengatur tata ruang kelas dan menciptakan iklim belajar mengajar yang sesuai)

4. Menggunakan media dan sumber belajar (mengenal, memilih dan menggunakan media yang bervariatif, membuat alatalat bantu pelajaran yang sederhana, menggunakan dan mengelola laboratorium,perpustakaan, dan microteaching yang disesuaikan dengan bidang studi yang diajarkannya)

5. Menguasai landasan-landasan kependidikan

6. Mengelola interaksi belajar-mengajar

7. Menilai prestasi mahasiswa untuk kepentingan pembelajaran

8. Mengenal fungsi dan program pelayanan bimbingan dan penyuluhan

9. Mengenal dan menyelenggarakan administrasi sekolah

10. Memahami prinsip-prinsip dan menafsirkan hasil-hasil penelitian pendidikan guna keperluan pembelajaran. (Usman, 2012:74) 
Setiap dosen memiliki pengalaman dan pemahaman yang berbeda tentang hakekat mengajar, setidaknya ada beberapa cara para dosen dalam melaksanakan perannya. Setiap cara itu memiliki implikasi terhadap bagaimana seharusnya mahasiswa belajar dan bagaimana seharusnya dosen mengajar.

\section{B. PEMBELAJARAN DI LPTK}

LPTK sebagai perguruan tinggi harus mengembankan pembelajaran bagi para dosen dengan cara menyegarkan kembali prinsip pembelajaran agar proses pembelajaran menjadi lebih kreatif, inovatif dan menyenangkan bagi kedua belah pihak dosen sebagai pendidik dan mahasiswa sebagai calon guru. Korelasi antara dosen dan mahasiswa yang dimaksud, agar mahasiswa aktif dan mau berpartisipasi dalam proses pembelajaran untuk mencapai prestasinya, dalam arti mahasiswa bukan aktif hanya sekedar mengerjakan tugas semata tetapi turut serta berpartisipasi dalam proses perkuliahan sebagai ajang latihan berbicara di depan forum kelas.

Perkembangan IPTEKS di era globalisasi secara tidak langsung telah menuntut adanya paradigma baru dalam dunia pendidikan yakni perlunya perubahan orientasi proses pembelajaran di kelas untuk mempersiapkan sumber daya manusia abab 21 (Mulyasa, 2012:22) . Hal ini diperlukan guna lebih membekali kemampuan peserta didik menghadapi tantangan hidup dikemudian hari secara mandiri, percaya diri, cerdas, kritis, rasional dan kreatif.

Dalam konteks persiapan sumber daya manusia abad 21 harus lebih mengacu pada konsep belajar yang dicanangkan oleh komisi UNESCO yang mencakup: learning to think, learning to do, learning to be dan learning to life together (Sudarminto, 2010). Model pembelajaran yang diperlukan adalah yang memungkinkan terbudayakannya kecakapan berfikir ilmiah, kemampuan berfikir kreatif, dan mampu menghasilkan kemampuan untuk belajar, bukan saja diperolehnya sejumlah pengetahuan, keterampilan, dan sikap (Zamroni, 2010).

LPTK sebagai lembaga pencetak perosil-personil yang akan bertugas dalam kancah pendidikan dan berhubungan langsung dengan siswa kelak tentunya dapat mempersiapkan calon-calon guru yang handal dan dapat menjawab semua harapan-harapan di atas. Zaini (2012:17 ) mengemukakan bahwa dalam mempersiapkan calon guru, dosen di LPTK dalam melaksanakan perannya dalam perkuliahan sesuai dengan sudut 
pandang tentang proses pembelajaran yang dilakukannnya.

Secara umum sebagian besar dosen memandang bahwa tugas mengajar adalah menyampaikan materi yang otoritatif atau mendemonstrasikan prosedur-prosedur pembelajaran yang telah didesainnya. Dalam hal ini pandangan tentang mengajar diambil dari anggapan bahwa dosen adalah sumber informasi yang tidak terdistorsi, sedangkan mahasiswa adalah penerima yang pasif. Pandangan terhadap aktivitas pengajaran seperti ini jika dianut oleh dosen akan mengakibatkan kegagalan belajar mahasiswa. Dosen-dosen tersebut mengaktualisasikan hubungan antara apa yang dilakukan oleh mahasiswa sebagai sesuatu yang secara instrinsik tidak bermasalah dan menganggap bahwa semua masalah belajar berasal dari luar diri dosen.

$$
\text { Pandangan lain, kegiatan }
$$
pembelajaran bergeser dari dosen ke mahasiswa. Mengajar dipandang sebagai kegiatan supervisei, proses yang melibatkan teknik-teknik yang didesain untuk menjamin mahasiswa belajar. Penguasaan materi secara otoritatif penting oleh dosen hanya menjadi latar belakang (background). Meningkatnya mutu pengajaran menurut pandangan ini adalah menambah daftar strategi dan model mengajar, bukan mengubah cara pandang dan pemahaman dosennya. Mempelajari teknik mengajar, menurut pandangan tersebut, merupakan dasar yang cukup untuk meningkatkan pengajaran.

Selanjutnya fokus perhatian tentang pembelajaran dipandang pula bahwa kegiatan mengajar dan belajar sebagai dua sisi yang tidak terpisahkan seperti sebuah koin. Mengajar, mahasiswa, dan materi yang akan dipelajari terkait satu dengan yang lain oleh sebuah sistem. Mengajar dipahami sebagai sebuah proses kerjasama dengan mahasiswa untuk membantu mengubah pemahaman mereka. Dengan kata lain, mengajar adalah membantu mahasiswa belajar. Mengajar menyangkut upaya menemukan kesalahpahaman mahasiswa, mendorong perubahan, dan menciptakan situasi atau konteks belajar yang dapat mendorong mahasiswa agar secara aktif bergelut dengan materi perkuliahan.

Pada hakikatnya pembelajaran calon guru di LPTK jika dicermati terlihat penekanannya pada konsep "adult learning" atau prinsip belajar orang dewasa yang menjadikan pengalaman sebagai guru, dikenal juga dengan experiental learning atau belajar berdasarkan pengalaman. Ramadhani (2009:6) mengemukakan prinsip belajar berdasarkan pengalaman ini digunakan untuk menjelaskan proses belajar yang dialami di dalam kehidupan sehari-hari dan dapat diterapkan di perguruan tinggi. 
Sylvi (2009: 16) mengemukakan ada beberapa faktor yang mendukung model pembelajaran ini di perguruan tinggi adalah sebagaiberikut.

1. Perubahan secara global meliputi persaingan yang semakin ketat diikuti dengan perubahan orientasi lembaga pendidikan, yakni perubahan persyaratan kerja.

2. Masalah semakin kompleks sehingga perlu disiapkan lulusan yang mempunyai keahlian di luar bidang studinya.

3. Perubahan cepat di segala bidang kehidupan sehingga diperlukan kemampuan generik atau transferabel skill.

4. Kurikulum yang masih berbasis content yang memerlukan penyesuaian dengan arah kebijakan pengembangan perguruan tinggi dari model berpusat pada guru-menuju pembelajaran yang berpusat pada siswa.

Sisi lain yang perlu juga dicermati dosen di perguruan tinggi, khususnya di LPTK adalah dalam penentukan strategi yang tepat perlu dipersiapkan segala sarana dan prasarana yang diperlukan. Kemudian tak kalah pentingnya dalam penyampaian materi pembelajaran, dosen harus memiliki antusiasme yang tinggi, artinya penuh semangat sehingga dapat menumbuhkan kesadaran mahasiswa bahwa belajar itu penting. Untuk itu dosen harus memiliki kompetensi akademik, kepribadian dan social dan profesional dalam tampilannya..

Dosen dapat pula dijadikan sosok yang menjadi model bagi mahasiswa. Dalam perkuliahan di LPTK, dosen harus berperan sebagai teladan dan motivator bagi mahasiswa calon guru, menjadi agen pengembangan pengetahuan, dan perubahan serta mampu mengarahkan mahasiswa. Selain menjadi pentransfer ilmu, dia juga harus mampu memberikan wawasan tentang perkuliahan yang akan disampaikan; menjadi mediator, fasilitator, dan sekaligus dinamisator bagi mahasiswanya agar mereka memiliki motivasi yang tinggi untuk belajar dan membekali diri untuk menjadi guru kelak.

Peran yang harus dilakukan oleh mahasiswa di LPTK dalam kegiatan belajar mengajar adalah dengan aktif mencari materi-materi yanag sesuai dengan topik-topik perkuliahan. Karena dengan mengikuti perkuliahan mahasiswa harus mempunyai bekal atau persiapan untuk didiskusikan di kelas. Dengan demikian, mahasiswa harus memiliki kemandirian tidak selalu bergantung pada dosen. Karena yang didapat dari dosen itu sebenarnya hanyalah sebagian kecil saja dari ilmu pengetahuan yang mahasiswa peroleh. Kegiatan ini mengacu pada 
penerapan pembelajaran yang lebih berfokus pada mahasiswa (Student Centered Learning) dan berangsur mengurangi pembelajaran yang menjadikan dosen sebagai sentral kegiatan pembelajaran (Teacher Centered Learning)

\section{MODEL PEMBELAJARAN KLASIK} DI LPTK

Pada pembelajaran tipe klasik, kegiatan dosen di LPTK yang utama adalah menerangkan dan mahasiswa mendengarkan atau mencatat apa yang disampaikannya. Mahasiswa harus mengikuti cara belajar yang dipilih oleh dosen, dengan patuh mempelajari urutan yang ditetapkan dan tidak banyak mahsiswa yang mampu untuk menyatakan pendapatnya. Situasi perkuliahan didominasi oleh segelintir mahasiswa yang berkemampuan lebih. Pembelajaran selama ini hampir tidak pernah dituntut untuk mencoba strategi dan cara (alternatif) sendiri dalam memecahkan masalah. Pengajaran model seperti itu sebagai suatu penyelenggaraan pendidikan ber-"gaya bank" (banking concept of education) atau dikenal juga dengan transfers is knowledge. Penyelenggaraan pembelajaran hanya dipandang sebagai suatu aktivitas pemberian informasi yang harus "ditelan" seseorang yang wajib diingat, dihafal yang suatu waktu akan ditanya dan evaluasi oleh dosen.

Di LPTK selama ini penyelenggaraan pembelajaran berfokus pada dosen lebih menekankan kepada tujuan pembelajaran berupa penambahan pengetahuan, sehingga belajar dilihat sebagai proses "meniru" dan mahasiswa dituntut untuk dapat mengungkapkan kembali pengetahuan yang sudah dipelajari melalui kuis atau tes terstandar. Pembelajaran berfokus pada dosen menekankan pada resitasi konten, tanpa memberikan waktu yang cukup kepada mahasiswa untuk merefleksi materi-materi yang dipresentasikan, menghubungkannya dengan pengetahuan sebelumnya, atau mengaplikasikannya kepada situasi kehidupan nyata yang bakal dihadapi mahasiswa.

\section{Penyelenggaraan}

pembelajaran berfokus pada pendidik ini lebih sering menggunakan modus telling (pemberian informasi), ketimbang modus demonstrating (memperagakan) dandoing direct performance (memberikan kesempatan untuk menampilkan unjuk kerja secara langsung). Dalam perkataan lain, dosen lebih sering menggunakan strategi atau metode ceramah dan atau drill dengan mengikuti urutan materi dalam kurikulum secara ketat. Dosen berasumsi bahwa keberhasilan program pembelajaran dilihat 
dari ketuntasannya menyampaikan seluruh materi yang ada dalam kurikulum. Penekanan aktivitas belajar lebih banyak pada pemahanan bahan ajar melalui buku teks, hand out atau diktat dan kemampuan mengungkapkan kembali hal-hal yang sudah ditugaskan untuk dipelajari dari semua bahan ajar yang diberikan.

Pada

pembelajaran berfokus pada dosen merupakan sebuah praktik yang mekanistik dan diredusir menjadi pemberian informasi. Dalam kondisi ini, dosen memainkan peran yang sangat penting karena mengajar dianggap memindahkan pengetahuan ke orang yang belajar. Dengan kata lain, penyelenggaraan pembelajaran dianggap sebagai model transmisi pengetahuan. Dalam model ini, peran dosen adalah menyiapkan dan mentransmisi pengetahuan atau informasi kepada mahasiswa. Sedangkan peran para mahasiswa adalah menerima, menyimpan, dan melakukan aktivitas-aktivitas lain yang sesuai dengan informasi yang diberikan oleh dosen yang mengampu perkuliahan.

\section{PENERAPAN STUDENT CENTER LEARNING DI LPTK}

Di LPTK, sebagai pencetak calon tenaga guru, dosen sebagai pendidik dan pengajar harus dapat menciptakan situasi dan kondisi agar mahasiswa dapat memproses informasi dengan lebih mudah dan cepat dipahami sekaligus melekat dalam ingatan mereka. Di sinilah dosen harus memperkenalkan berbagai model dan strategi belajar dan mengajar kepada mahasiswa.

Dalam penerapan model dan strategi pembelajaran tersebut dosen harus berkomunikasi secara efektif dengan mahasiswa untuk menciptakan suasana dialogis secara bebas yanag dapat merangsang semangat belajar mahasiswa. Dosen harus berperan sebagai teladan dan motivator bagi peserta didik, menjadi agen pengembangan pengetahuan, dan perubahan serta mampu mengarahkan mahasiswa. memiliki motivasi yang tinggi untuk belajar.

\section{Student Center Learning (SCL)}

sebagai alternatif dalam pembelajaran dan interaksi edukatif merupakan model pembelajaran yang lebih edukatif dan inovatif berorientasi pada kegiatan mahasiswa. Peran dosen dalam proses pembelajaran model SCL memiliki peran yang penting, meliputi:

1. Bertindak sebagaifasilitator dalam proses belajar mengajar.

2. Mengkaji kompetensi matakuliah yang perlu dkuasai mahasiswa di akhir pembelajaran.

3. Merancang strategi dan lingkungan pembelajaran yang dapat menyediakan bergam pengalaman 
belajar yang diperlukan mahasiswa dalam rangka mencapai kopetensi yang dituntut mata kuliah.

4. Membantu mahasiswa mengakses informasi, menata dan mmeprosesnya untuk dimanfaatkan dalam pemecahan permaslahan sehari-hari.

5. Mengidentifikasi dan menetukan pola penilaian hasil belajar mahasiswa yang elevan dengan kompetensi yang diukur. (Depdiknas, 2004:37)

Dalam pelaksanaan model pembelajaran SCL mahasiswa mempunyai peranan yang tidak kalah penting karena mahasiswa termasuk salah satu yang ikut menentukan proses pembelajaran model ini berhasil atau tidak. Peran mahasiswa adalah sebagai berikut.

1. Mengkaji kompetensi matakuliah yang dipaparkan dosen.

2. Mengkaji strategi pembelajaran yang ditawarkan dosen.

3. Membuat rencana pembelajaran untuk mata kuliah yang diikuti

4. Belajar secara aktif dengan cara mendengarkan, membaca, menulis, diskusi, dan terlibat dalam pemecahan maslah serta lebih penting lagi terlibat dalam kegiatan berpikir tingkat tinggi, seperti analisis, sintesis dan evaluasi., baik secara individu maupun kelompok.(Depdiknas, 2004:37)

Keberhasilan SCL, selain menjadi tanggung jawab dosen di LPTK tentu nya memerlukan pula inisiatif dan upaya bersama dari pihak mahasiswa. Keberhasilan pembelajaran yang ditandai dengan efektivitas dan efesiensi pengelolaannya oleh dosen. Mahasiswa komponen penting dalam pengelolaan tersebut yang harus berkoloborasi dan menunjukkan minat dan motivasi untuk mencapai hasil pembelajaran yang maksimal. Froe dan Lee dalam Supriyoko (2008:6) mengemukakan bahwa keberhasilan mahasiswa di perguruan tinggi yang dapat dijadikan penunjang untuk keberhasilan SCL diantaranya dibarengi dengan hal hal-hal berikut ini.

1. Lakukan studi terhadap suatu mata kuliah atau bahan pelajaran pada waktu yang sama setiap hari, apabila mungkin.

2. Jangan belajar sewaktu keadaannya terlalu santai.

3.Hindarkan studi yang serius setelah kenyang makan.

4 Berbuatlah sesuatu ketika belajar; misalnya menulis, membuat catatancatatan, ringkasan- ringkasan, dan sebagainya. 
5. Pergunakan waktu yang cukup untuk belajar; jangan terlalu membatas waktu.

6. Setelah duduk di kursi belajar segeralah pelajaran dimulai untuk mempercepat terbentuknya konsentrasi belajar.

7. Sisihkan waktu satu jam/minggu untuk pengulangan setiap materi mata kuliah.

8. Jangan terlampau banyak kegiatan di luar kelas agar tidak menyita waktu belajar.

12. Sewaktu berada di dalam kelas, jangan pikiran melayang-layang ke luar kelas.

13. Ujilah pengetahuan dan pemahaman anda tentang sesuatu masalah.

14. Buatah contoh-contoh terapan materi yang dipelajari.

15. Carilah kasus-kasus praktis bagi pengetahuan anda yang baru didapat.

16. Usahakan mempunyai gambaran utuh pada setiap topic.

17. Catatlah dan persiapkan semua tugas belajar.

18. Upayakan kebiasaan belajar dan motivasi diri untuk mencapai prestasi.

19. Hubungkan pengetahuan baru dengan pengalaman terdahulu;

20. Bagilah kegiatan belajar anda untuk semua mata kuliah sehingga masingmasing akan mendapatkan kesempatan secara proporsional.

21. Jangan melakukan studi terhadap bahan-bahan yang sejenis dalam satu urutan; hal ini seringkali justru akan membuat salah persepsi.

22. Belajar tentang masalah-masalah yang lebih penting sebaiknya didahulukan sebelum tidur atau berekreasi.

23. Latihlah kebiasaan belajar tuntas

24. Lakukanlah pekerjaan atau eksperimen yang tujuannya jelas di laboratorium; misalnya, pertanyakan sebenarnya apa diinginkan dalam satu percobaan.

25. Perhatikan sungguh-sungguh terhadap grafik, gambar atau daftar agar persepsi yang dimiliki akan menjadi tuntas.

26. Perhatikan secara teliti kata-kata baru atau tek-nik-teknik baru sewaktu mendengarkan atau membaca.

Selain dosen dan mahasiswa, yang tidak kalah penting lagi peran LPTK itu sendiri. Untuk keberhasilan pembeajaran model SCL dapat diimplementasikan secara efektif dan efesien maka perguruan tinggi LPTK mempunyai peranan sebagai berikut.

1. Mengkaji kurikulum, program pembelajaran dan sistem penilaian hasil belajar yang mengacu pada SCL;

2. Membuat kebijakan tentang sosialisasi dan penerapan SCL di institusinya.

3. Menciptakan lingkungan belajar yang kondusif untuk terlaksananya SCL 
dengan menciptakan networking dengan dunia kerja, lembaga-lembaga masyrakat, atau instansi yang terkait.

4. Membenahi pola pikir (mindset) para dosen dan pengelola program pendidikan pada umumnya tentang pentingnya mengubah paradigma mengajar berorientasi pada dosen semata pada pola pembelajaran berorientasi pda mahasiswa, yang dicirikan dengan adanya interaksi positif dan konstruktif antara dosen dan mahasiswa dalam pembangunan pengetahuan.

5. Melatih dan memberikan dukungan yang enuh kepada para dosen dalam menerapkan SCL dalam proses pembelajaran.

6.Memanfaatkan

perencanaan pembelajaran yang berorientasi SCL, yang dikembangkan para dosen, dalam pengadaan sarana-prasarana pendukung pembelajaran.

6. Menciptakan sistem yang memunukinkan dosen dan seluruh civitas akademika dapat berkomunikasi dan berkoordinasi serta akses terhadap IT (information technology) (Depdiknas, 2004: 38).

Beberapa karakteristik berikut juga menjadi keharusan dalam pelaksanaan SCL yaitu: adanya berbagai aktivitas dan tempat belajar, display hasil karya mahasiswa, terdapat materi belajar yang banyak, tersedianya tempat yang nyaman untuk berdiskusi, terjadinya kelompokkelompok dan interaksi multi-angkatan. Dan yang tak kalah pentingnya pula adanya keterlibatan dunia bisnis/industri dan masyakat lainnya serta jam buka perpustakaan fleksible (Harsono, 2005:17) Pemahaman peran dari ketiga elemen utama prosses pembelajaran sebaaimana diuraikan di atas, akan mampu mendukung efektivitas metode-metode pembelajaran yang masuk dalam klasifikasi model pembelajaran SCL. Adapun metode-metode yang dimaksud adalah Small group discussion, Role-play and simulation, Case study, Discovery learning, Self-directed learning, Cooperative learning, Colloborative learning, Contextual learning, Project based learning, Problem based learning and inquiry (Depdiknas, 2004:36)

Penerapan proses pembelajaran berbasis SCL pada mahasiswa di LPTK dibarengi pula dengan suasana akademik yang kondusif. Beberapa karakteristik yang harus terpenuhi jika sebuah perguruan tinggi menerapkan SCL, yaitu adanya berbagai aktivitas dan tempat belajar dan selain itu yang tak kalah pentingnya adalah penataan dan manajemen yang perguruan tinggi yang baik akan dapat berkontribusi positif pada masa studi mahasiswa, peningkatan IPK, meningkatkan kemampuan problem 
solving, dan mempersingkat penyelesaian tugas akhir. Hal ini bahkan dijadikan indikator yang menunjukkan keberhasilan dan kualitas lulusan sebagai calon guru, bahkan kualitas sebuah LPTK

\section{E. PENUTUP}

Penerapan model pembelajaran SCL memerlukan beberapa strategi yang dapat dilakukan anatara lain degan mengubah paradigma dosen tentang sesuatu yang terlibat dalam proses belajar mengajar, yaitu proses belajar tersebut, mengajar, dan pengetahuan. Dengan adanya pengubahan paradigma tersebut, yang perlu dilakukan lagi adalah melakukan revisi kurikulum, baik dari segi substansi kurikulum tersebut maupun proses penyampaiannya. Dengan demikian diharapkan mahasiswa lulusan LPTK yang dibiasakan dengan pembelajaran SCL akan memiliki sikap, pengetahuan dan keterampilan sebagai capaian perkuliahan yang handal. Lulusan LPTK sebagai calon guru yang sudah memiliki pengalaman dalam penerapan SCL yang digunakan dosennya akan diinternalisasinya dan dijadikan bekal nanti dalam perwujudan kompetensi profesionalnya di sekolah.

Pada dasarnya dosen adalah seorang pendidik. Pendidik adalah orang dewasa dengan segala kemampuan yang dimilikinya untuk dapat mengubah psikis dan pola pikir mahasiswa yang dididiknya. Dalam penerapan SCL, salah satu yang paling penting juga bagi dosen adalah performance dosen di kelas. Bagaimana seorang dosen dapat menguasai keadaan kelas sehingga tercipta suasana belajar yang menyenangkan.

Pemahaman tentang karakteristik mahasiswa penting dilakukan, mencakup kebiasaan, gaya belajar, minat dan harapan-harapannya setelah belajar. Mahasiswa sebagai calon guru tentunya dosen juga akan menjadi model bagi mahasiswa nanti jadi guru. Dengan demikian model pembelajaran yang digunakan dosen selain dapat meningkatkan hasil pembelajaran atau capaian hasil belajar mahasiswa sekaligus jadi rujukan dan model penerapan SCL di sekolah jika mahasiswa terjun di lapangan menjadi guru. Akhirnya, penerapan SCL dapat dijadikan alternatif bagi LPTK meningkatkan mutu calon guru, khususnya dalam peningkatan kompetensi sebagai tenaga profesional dan mutu pendidikan pada umumnya.

\section{REFERENSI}

Dewajani, Sylvi. 2009. Student Cenered Learning," materi Lokakarya Peningkatan Kualitas Teknik Pembelajaran Student Center Learning. Yogyakarta: Pusat 
Pengembangan Pendidikan Universitas Gajah Mada.

Depdiknas. 2004. Tanya Jawab Seputar Unit danProses Pembelajaran di Perguruan Tinggi. Jakarta: Departemen Pendidikan Nasional.

Harsono. 2005. "Aplikasi SCL dan Proses Pembelajaran”.

Dalam www.belajar.usd.ac.id/

Mulyasa. 2013. Kurikulum Berbasis Kompetensi. Bandung: PT Remaja Rosdakarya

Peraturan Pemerintah No.19 tahun 2005 tentang Standar Nasional Pendidikan

Ramadhani, Neila. 2009, Ruh Experiental Learning dalam SCL," dalam Http://neila.stafff.ugm.ac.id/?pilih= $\underline{\text { lihat\&id=10 }}$

Sudarminta. J. 2010. Tantangan dan Permasalahan Pendidikan di Indonesia Memasuki Milenium Ketiga. Yogyakarta: Kanisius

Supriyoko. 2008. Kunci Sukses Belajar di Perguruan Tinggi.Yogyakarta: KR,

Undang-Undang Nomor 14 tahun 2005 tentang Guru dan Dosen

Usman, Nazir. 2012. Manajemen Peningkatan Mutu Kinerja Guru (konsep,Tiori dan Model), Bandung, Cita Pustaka

Zaini, Hisyam. 2012. Desain Pembelajaran di Perguruan Tinggi. Yogyakarta: CTSD IAIN Sunan Kalijaga.
Zamroni. 2010.
Paradigma
Pendidikan
Masa Depan.
Yogyakarta:
BigrafPublishing 